\title{
Chemistry, Theater, Information and Communications Technology
}

\author{
María de los Ángeles Montiel Montoya ${ }^{1 *}$, Celia Sánchez Mendoza ${ }^{2}$ and Graciela Martínez de Jesús ${ }^{1}$ \\ 1. Department of Chemistry, National Preparatory School No. 4, National Autonomous University of Mexico, Mexico 11870, Mexico \\ 2 Department of Chemistry, National Preparatory School No. 8, National Autonomous University of Mexico, Mexico 01600, Mexico
}

\begin{abstract}
Theater play that shows how textiles, make up, hair dyes and music players has changed along the last six decades, especially due to polymers. It is a play that has a historic, chemical and musical side that introduces the use of ICT (information and communications technology), such as Facebook, Moodle platform, Web sites, E-mail, Word, Publisher, PowerPoint, Videos and Digital music. Results in the conduct of the students that participated: assertiveness, self-esteem, tolerance, cooperation, responsibility and teamwork, all of them significantly contributed a meaningful learning about the polymers.
\end{abstract}

Key words: Theater, ICT, polymer, meaningful learning.

\section{Introduction}

To refer to the art of theater means to date back to the origins of the history of mankind, those days when the wizards of the tribes used to dance with music and chants in order to overcome the power of the bad spirits. In the ancient times of Greece, bad spirits finally surrendered to the Gods, that is why the Greeks danced with costumes of male goats in honor of Dionysus or Bacchus [1].

The audience was equally interested in the suffering of the Gods as much as in the performance and jumping around of the satires; that is how tragedy and comedy were born. The origin of theater is religious; the stories of heroes and kings came up later. Athens was the seat of theater constructions, which became the model of modern edifications: scenery, proscenium, orchestra and all the accessories around the performance, depending on the subject of the representation. In both, Greece and Rome, theaters were financed by the government and in all the territories that were conquered by both empires, theaters were constructed. Since then, theater has

\footnotetext{
*Corresponding author: María de los Angeles Montiel Montoya, bio-pharmaceutical chemist, rearch filed: learning strategies. E-mail: maangel@unam.mx.
}

been considered as an artistic, cultural and esthetic activity that fulfills social, psychological, therapeutic, didactic and educational aims where dialogues, action, music and decoration are part of the ritual of theater [2].

During the middle age, theater was used as a didactic mechanism - drama emerged from liturgy to teach the testament. During the Renaissance, Jesuits made an educational instrument out of it in schools and in convents where the representations were mainly in Latin and German [3]. It was on those days, when Juan Luis Vives wrote dialogues in order to teach Latin to University students [4, 5]. In Mexico, the origin of theater is also religious, as it relates to the Spanish sacramental texts, during Christmas, Pastorelas were performed, nowadays we still stick to that tradition [6].

Theater can be considered mainly as an audiovisual art because it is generated on the basis of image and sounds; though, theater without sound and images also exists, such as mimics and representations in radio. It is usually a unilateral way of communication because the actor sends the message without the direct participation of the audience. Nevertheless, in 1973, with the presentation of the environmentalist theater, 
"The Performance Group", according to its author Schechner, "the invisible barricade between audience and scenery disappears, as all the space becomes multidimensional”, in other words, the audience takes part of the representation [7].

Nowadays, it is common to attend to representations in schools [8]. Theater is used by teachers of artistic, social and humanistic subjects in order to perform any esthetic, social or political situation involved in their subjects, but this field has not been properly exploited by science professors as a didactic and participative experience that contributes to develop improvisation, creativity, spontaneity, interaction between actor and audience and group participation [9]. In modern times, dramatization techniques consider teaching as one process, where theory and practice feed each other in all their cognitive, affective, perceptive, psychomotor, artistic and social developmental aspects [10].

Over two thousand years ago, Plato, in the "Republic", suggested to teach with amusement; he was able to foresee what was proved in modern times about theater being an amusing way to educate as well as an excellent didactic instrument, due to its teaching and learning process, which implicates both emotive and rational factors, where actor and spectator are related equally in the affective, intellectual and communicative fields. Its educational technique is based in pedagogical principles such as a unitary and active education and an enthusiastic teaching methodology as it takes advantage of a grand variety of strategies that represent a way of expression that combines speech, movement, music, sounds, gestures, choreography, scenery and sometimes, even chants.

In other words, theater's function is to educate, to form a morality, to amuse, to sublime, etcetera and as an educative field, it is one of the pedagogical techniques that is used to develop the expression and communication capabilities of students. Therefore, theater is a powerful didactic resource, as it invites the audience to think about a problem, to understand a situation and to adopt a moral view, which leads to a development of multiple skills of students, such as body communication, creativity, social abilities, language, history, literature and even chemistry.

Out of the seven types of theater-tragedy, comedy, tragicomedy, musical, didactic, melodrama and farce, we have focused our experimentation in melodrama style. Its main function is to amuse and we consider fun to be one of the most fundamental needs of mankind, that can be achieved through many mechanisms such as learning, recognition, creativity, association, games and satire, all of them are related to emotions and the way they are dealt with. Because of all these factors, the style of the play that was performed was a melodrama mixed with comedy [11].

\section{Experimental Sections}

The objective is to motivate the learning of Chemistry in a playful way and to develop chemistry in ordinary life based on the use of ICT (information and communications technology) through artistic manifestations, such as theater. We, as Chemistry teachers and also the authors of the play, are totally convinced that theater is a powerful didactic mechanism that should be applied inside and outside the classroom, with the most recent technology of ICT. This conviction is based on our experience preparing and performing plays and puppets. Two of the authors, Montiel and Sánchez, have been doing this since 1995, they both got to know each other's work, in that same year, on April 7th, during the "V Science and Humanities Fair", specifically during an exhibition named "Scientific Revolutions" which took place in the Southern Campus of the Science and Humanity College, that belongs to the National Autonomous University of Mexico [12]. From that date until now, we have not stopped teaching in that amusing method, as we both work in the same school and during the same schedule. We have fifteen unpublished plays 
(some of the puppets plays were written by the students) and some others like "Little Mirror, little mirror ..." and "Modeling the future" were written, performed and copyright registered in 1995 and 1999 by Montiel respectively.

Why should we support Chemistry lessons with theater? Because the majority of the students believe that Chemistry is a complicated, difficult and abstract subject, so with the use of other sources, such as theater, it can be taught in a playful and dynamic way. Besides, since the students are the active participants on the plays, they are responsible for their own learning and at the same time they make sure they have fun. On the other hand, society requires an education that contemplates the development of technology and science and even though, it is true that students use a lot and all kinds of technology, it is not always properly focused on accomplishing their learning process. When the teacher bases its methods on the use of ICT, the teaching-learning process is benefited. So, the use of both, ICT and theater, applied to chemistry subjects, can improve the quality of this process [13].

\subsection{Methods}

The play was written by the authors in a melodrama mixed comedy style for the audience to have fun and learn about the history and uses of the polymers back in the 1950s and until recent times. We included modeling, choreography with different types of dancing according to the different periods during those years. All those elements were joined through the dialogues that were performed by the three teachers involved, which sometimes were comic, each of them recalled the days when they were high school students, referring to the 1950-1960s, 1970-1980s and the 1990s up until the recent time, each period assigned according to their ages. The coffee shop, which was supposed to be the set in the High School number 4 , was the place where the teachers sat down during the whole play, and each one would stand up to tell their own dialogue.

The play is called "Past and recent youth in Chemistry", as it refers to the students that have actually studied Chemistry in High School, Number 4, since 1953. It was written for the celebrations of the 60th Anniversary of the High School, Number 4 of the National Autonomous University of Mexico so it was performed in February 15th, 2013, in its auditorium. More than eighty students, out of the nine groups that were studying Chemistry, participated voluntarily. The students decided to divide themselves in teams in order to take care of the entire production, scenery, choreography, dressing, direction, decoration, illumination, posters of propaganda and the programmes. Some female students were the hosts and some male students took care of the safety of the place and the entrances. They used this occasion as the chance to expose the artistic and esthetic abilities of the mandatory theater, dancing, music and visual arts classes they took in previous levels. Professor Jorge Alberto González Cano was responsible of the music and it was burn into a CD. The proper preparation of the choreography was taken care by each group. Though some students were not able to attend all of the rehearsals, it did not affect the performance, as their enthusiasm, responsibility and devotion balanced those absences.

ICT were used when participants took part in the posters competition (E-mail, Web sites, Facebook and Moodle platform); posters were elaborated with Word, PowerPoint and Publisher, only the first four places were printed and were used for the propaganda of the play. The technique to be used in the elaboration of the posters was left to be chosen by the students, who could also choose to work by themselves or in teams. The award consisted in the possibility of the posters to be printed and the first place, got to be incorporated in the programmes.

A surprise was given to all the students that participated in the play, as one of the teachers produced a Video out of different pictures of them 
taken from Facebook, and it was shown before the first call and as everybody was taking their places; during the second call, another Video was shown, it was about the history of the school. And then, after the third call, the play started, and the students performed all the dialogues through the Modeling, Choreography, Videos and PowerPoint of the different polymers, referring to their proper names, structures and uses in the last sixty years [14].

\section{Results and Discussion}

The main theme of the play was to show the different uses of polymers that are taught during Chemistry III and IV in $5^{\text {th }}$ and $6^{\text {th }}$ grades, at the High School. This topic has been empirically proved to be complicated for the students, as the level of the difficulty in the structures and chemical reactions taught is remarkable.

The play was divided in the last six decades, in order to show the development of polymers and how they were applied in fashion (dresses, hair dye and spray, make up), electronic devices (disc player, discman, walkman, ipod) and electronic accessories (LP, CD, USB). The polymers shown were nylon, polyvinyl chloride, polyester, polyethylene and polytetrafluoroethylene, etc.

The main purpose of the play was to show how students used to live back in 1953, during the origins of the school represented and how it changed from one decade to another; the last performance was the demonstration of the most recent gym clothes, that are water proof but allow perspiration of the body, which came on the market in the last decade of this century, the group in charge of this scene represented cheerleading, jumping and playing, as the other students came up into the scenery and all together performed all the different cheers that have existed in all the generations of the school; the audience joined the singing with the actual cheers and that was the end of the play. Laughs and applauses could be heard for some minutes. The principal of the school went on the scenery to congratulate all the students and ourselves, the authors, and that was the closure of a week of celebrations in honor of the 60th Anniversary of High School, Number 4, UNAM.

Teachers of different subjects came to congratulate us and to let us know that they would never forget the history of polymers and their uses. Although there was not a formal measure of the impact and results of the play, plenty of good commentaries were known along the students pointing out the amusement they had, the quality of the play and what they learned about polymers. Actually, many students asked for the play to be performed again in the afternoon schedule, though, timing and the difficulty of organizing 80 students from three different class groups did not allow us to fulfill the request. Students were actually able to live the experience of the interrelation of arts, science and ICT.

With the performance of the play, students were able to develop or increase their motor abilities as well as their memory, as they had to know their dialogues, choreography, gestures, their public performance and speaking with a good pronunciation and a clear voice and sound. They also were able to work and show their values and good attitude as they were able to work in groups that collaborated and worked with respect, responsibility and commitment.

\section{Conclusions}

Difficult chemistry concepts to be understood, such as polymers, were able to combine with many artistic manifestations (theater, dance, music) and ICT thanks to the performance of the play. The best mixture between science, art and technology was made out of the play and it also made possible for students to have fun as they learned considerably as well as they laughed considerably.

Education is based on pedagogical principles. An active and complete education based on amusement and ICT is possible with theater. Plus, rational and emotional abilities are motivated in both the actor and 
the audience.

Teaching in a class about polymers is well reinforced when the solemnity of the classroom transforms into the amenities of a play, it is a genuine way to learn, as the students get involved directly with the subject in study.

Many good commentaries came out of the auditory, such as affirming that they would never forget what a polymer is and its uses. Different children attending the play were seen focused on it and really enjoying it. The play was asked to be performed again in the coming year.

Theater is not only a great mechanism of artistic expression; it is also an ideal way of communication, through music, gestures, movements, space, time, emotions. Albert Mehravian [15] showed how in communication $7 \%$ is in words, $38 \%$ is out of the voice tone and $55 \%$ comes out of gestures and movements. So, if we add up the use of ICT, the learning skills are increased in all areas, including Chemistry.

Theater develops teaching strategies through playful experiences that also motivate an affective work in students allowing learning of difficult concepts, in this case, polymers, that also makes it possible to increase their social abilities such as assertiveness, team work, self-esteem, tolerance, cooperation, creativity and responsibility.

Due to the nature of theater, we believe that it is an educational mechanism that can be easily used in students, as it is based on having fun and producing a meaningful learning.

\section{Acknowledgments}

The authors thank Professor Jorge Alberto González Cano for his participation in the poster contest, in their elaboration and for being part of the jury and for choosing the music and burning it into a $\mathrm{CD}$.

We thank all our students of Chemistry III of $5^{\text {th }}$ grade and of Chemistry IV of $6^{\text {th }}$ grade that took class with us during 2012-2013, especially those that performed the play "Past and recent youth in Chemistry", as their commitment and enthusiasm were remarkable.

\section{References}

[1] Theater Group. 2010. The Other Window: History Theatre Universal-Theatre Origins. Blog laotraventana.obolog.es.

[2] Avitia, A. 1984. Theater for Beginners. México: Tree Publisher.

[3] Asenjo, J. 2012. Colonial Jesuit College Theater of Mexico to Chile. University of Valencia. https://books.google.com.mx/books?id=3graAwAAQBAJ \&pg=PT19\&lpg=PT19\&dq=bernabe+bartolome+martine $\mathrm{z}+$ biografia\&source $=$ bl\&ots $=$ WmcbbinLzS\&sig $=P W a 4 Q$ H9MrBbThth7sbmi0jtmBdM\&hl=es\&sa=X\&ved=0CB4 Q6AEwATgKahUKEwjzjbusvI3GAhWESpIKHa6QAB4 \#v=onepage\&q=bernabe\%20bartolome\%20martinez\%20 biografia $\& \mathrm{f}=$ false-.

[4] Martínez, B. 1992. A Biobliografic Research on the Figure and Pedagogical Work of Juan Luis Vives. 1492-1540.

http://revistas.ucm.es/index.php/RCED/article/viewFile/R CED9292110119A/18036.

[5] Navarro, A. 2006. Theater in Education. http://es.wikipedia.org/wiki/Teatro_en_la_educación.

[6] Vasquez, A. 2012. History about Pastorelas. http://anavasquez.com/2012/12/la-historia-de-las-pastorel as/.

[7] Schechner, R. 1973. Enviromental Theater. Mexico: Tree.

[8] Baldoví, J. 2010. Scientific Culture Divulgation Blog of Science, Technology and Environment. Chemistry Theater.

http://cienciacultural.wordpress.com/2010/04/18/teatro-q uimico/\#comment-18.

[9] La, P. 2011 Singing and Theater are Tools for the Chemistry Learning. Accessed May 12, 2013 and June 2015. http://lapatriaenlinea.com/?nota=88991.

[10] Romero, L., and Margarita. 1961. "The Theater in Elementary School.” Thesis, National Teacher School.

[11] Rivera, V. A. 1993. Dramatic Composition. Mexico: Group Publisher Gazette.

[12] Montiel, A. and Sánchez, C. 2002. "The Theater as a Didactic Tool, 7 Years of Experience in the National High School Number 4." Chemistry Teacher Meeting, Mexico. 
[13] Larraz, R. 2008. The Theater as a Didactic Tool. Accessed May 2013 and June 2015. http://www.cuadernointercultural.com/el-teatro-como-rec urso-pedagogico.

[14] Sánchez, C., Montiel, A., Martínez, G. 2013. Past and
Recent Youth in Chemistry (Fragments of the Play). https://youtu.be/6ny6xFiSzsI published 14 of June 2015 by Fernando Cruz Cortes.

[15] Mehravian, A. and En Peace, 2000. A Body's Language. Buenos Aires: Planet Publisher. 